\title{
A Brief History of Islamic Civilization from Its Genesis in the Late Nineteenth Century to Its Institutional Entrenchment*
}

\author{
KeVIn VAN Bladel \\ Yale University
}

(kevin.vanbladel@yale.edu)

\begin{abstract}
This article sketches the early history of Islamic civilization from its genesis in the late nineteenth century to its institutionalization in the twentieth. Key moments include its enshrinement in journals and a monumental encyclopedia and the flight of European Semitists to the United States. Its institutionalization in the undergraduate curriculum at the University of Chicago in 1956 created a successful model for the subsequent dissemination of Islamic civilization. Working in a committee on general education (the core curriculum) in the social sciences at the University of Chicago, Marshall Hodgson inaugurated Islamic civilization as a subject of university study that was not just for specialists but available to American college students as fulfilling a basic requirement in a liberal arts education. Many other universities followed this practice. Since then, Islamic civilization has come to be shared by the educated public. Today it is an internationally accepted and wellfunded entity that confers contested social power but still lacks analytical power.
\end{abstract}

$\mathrm{T}$

The purpose of this article is briefly to trace the development of Islamic civilization from its beginning in the nineteenth century, in the intellectual context of its formation, to the middle of the twentieth century, when it became a part of institutions that ensured its reproduction. After that, Islamic civilization becomes too widespread and too various for me to capture in short compass. Others may wish to pursue that difficult task. Nevertheless, I do reflect in conclusion on the ramifications of Islamic civilization for university curricula.

* I thank the three anonymous reviewers of this article for suggestions that have improved it. I also thank the discussants and participants at the symposium "Fifty Years after Marshall Hodgson and the Idea of a Discernible Islamic Civilization," held at Yale Law School's Abdallah S. Kamel Center for the Study of Islamic Law and Civilization, November 9, 2018, for their thought-provoking responses to an early version of the article. The shortcomings that remain are my own responsibility.

(C) 2020 Kevin van Bladel. This is an open access article distributed under the terms of the Creative Commons Attribution-NonCommercial-NoDerivatives License, which allows users to copy and distribute the material in any medium or format in unadapted form only, for noncommercial purposes only, and only so long as attribution is given to the original authors and source. 
"Islamic civilization" is common currency in English, as are its equivalents in other languages. It appears in the titles of books, in the names of university courses and wealthy foundations, and in the programs of policy think tanks. It is a widely accepted framework for explaining a large part of human history. Historians of Islamic civilization understand that it is a problematic concept, but they have normally been satisfied to leave it undefined or to deploy ad hoc definitions. Specialists often use the term merely out of convention or convenience. ${ }^{1}$ Recent efforts to analyze it are either tangential to a larger concern to define Islam itself, a different project, ${ }^{2}$ or part of Muslims' efforts to develop a transnational Muslim community for coordinated social and political action. Neither of these aspects of the problem is discussed here. I do not address debates about the nature or definition of Islam or of religion itself. Although the religion of Islam and Islamic civilization are frequently equated or used interchangeably, only the latter is discussed here. I will, however, inadvertently shed some light on their conflation.

Where, then, did Islamic civilization come from, and how did it become entrenched? Islamic civilization has a history. Its own myth of its origin posits a beginning in the seventh century, but it did not originate with Muhammad or with any caliph. No early Muslims ever even mentioned "Islamic civilization." Some early Muslims did eventually come to talk about events that happened "in Islam" (fi al-islām), using the term to refer to an ongoing period contrasting with what came before, and Muslim jurisconsults did develop a concept

1. For example, J. W. Meri writes in the editorial introduction to Medieval Islamic Civilization: An Encyclopedia, 2 vols. (New York: Routledge, 2006), 1:xi, "Such fundamental questions as to what Islamic civilization is ... remain largely unanswered." Neither the introduction nor any article in this reference work on Islamic civilization defines its subject. Another recent example is C. Robinson's Islamic Civilization in Thirty Lives: The First 1,000 Years (Berkeley: University of California Press, 2016). Robinson says in the introduction that he means by Islamic civilization "the distinctive yield, in lived experience and especially high culture, of the religious and political project undertaken by Muslims over the near millennium that spans from the seventh to the sixteenth centuries." It seems to be a term of convenience to put thirty interesting biographies of Muslims into one book. The idea that Islamic civilization is defined by its "high culture" is owed especially to von Grunebaum and Hodgson, whose impact is discussed below.

2. See, e.g., A. Karamustafa, who relies on the Islamic civilization concept to define Islam in "Islam: A Civilizational Project in Progress," in Progressive Muslims: On Justice, Gender, and Pluralism, ed. 0. Safi, 98-110 (Oxford: Oneworld, 2003). Similarly, S. Ahmed directly criticizes the Islamic civilization model in defining Islam (along with most other major models for the study of Islam), but then substitutes his own expression for a 500-year period of it, dubbing it the "Balkans-to-Bengal complex" of 1350-1850. The "Muslims (and others)" inhabiting this broad region in this period, he maintains, participated in "a common paradigm of Islamic life and thought" that admitted of internal contradiction. Despite the different terms and emphases, this is, practically speaking, the same as Hodgson's Islamic civilization bound by an elite culture of letters, which I discuss below. See S. Ahmed, What Is Islam? (Princeton, NJ: Princeton University Press, 2016), 73-85 and 153-75. Ahmed's explicit goal is "to provide a new language for the conceptualization of Islam," so the new terminology is not surprising. Whatever the results of their investigations, neither Karamustafa nor Ahmed are searching for the reasons we talk about Islamic civilization; rather, they are attempting to define Islam as Islamic civilization or by means of a closely similar stand-in concept. Of the many reviews of Ahmed's book, see especially F. Griffel, "Contradictions and Lots of Ambiguity: Two New Perspectives on Premodern (and Postclassical) Islamic Societies," Bustan: The Middle East Book Review 8, no. 1 (2017): 1-21. 
of the Domain of Islam (dār al-islām) for rulings about residence and warfare. ${ }^{3}$ These terms, like the Qur'ānic concept of umma, or religious community, deserve historical studies to elucidate their development, but they were not intended to define a discrete and ideally uniform transnational civilization and its contents to serve as one subject of a world history in contrast or comparison with distinct, non-Islamic civilizations.

The story told here involves very few Muslims. That, in itself, reveals something about the origins of Islamic civilization. Some have suggested to me that the identification of individual Muslim intellectuals who used similar (but different) concepts here and there might bequeath analytical validity to the present use of the term and increase its utility. But even if one were to discover a premodern "insider" concept of Islamic civilization-perhaps an Arabic word that once served a purpose like that of the English expression-it would not explain the modern use of Islamic civilization, which arose in historical circumstances peculiar to Europe, which I shall outline. Islamic civilization came into existence without recourse to parallel "native" concepts. Otherwise we might have used those terms instead. ${ }^{4}$ Attempts to validate the use of Islamic civilization for analysis on the basis of Arabic terms are afterthoughts. Islamic civilization first appeared among non-Muslim Europeans. To understand it, the concept, its institutionalization, and its reiteration in the outlook of individuals, one must begin with its component parts.

\section{Civilization}

The term "civilization" appeared in English in the sixteenth century, but it became current in the eighteenth, when it referred at first to the progress of the Civil Law as followed in Catholic Scotland and on the Continent against other kinds of law, such as English Common Law. In these early English uses, it meant the subjugation of the Scottish Highlanders, who had their own customary clan laws, and the imposition on them, as barbarian savages, of the Civil Law of the Scottish Lowlanders. That is what the English word civilization meant when Samuel Johnson debated its use as a neologism for his A Dictionary of the English Language (1755). Thus, already in its earliest uses in English, the new word civilization implied the contrast of regulated and refined city-dwellers with anarchic savages. By the 1820 s, the term civilization referred to the development of manners and improvement with

3. S. Albrecht, "Dār al-Islām and Dār al-Ḥarb," in Encyclopaedia of Islam, 3rd ed., ed. K. Fleet, G. Krämer, D. Matringe,J.Nawas, and E. Rowson (Leiden:Brill Online), http://dx.doi.org/10.1163/1573-3912_ei3_COM_25867.

4. Ibn Khaldūn (d. 808/1406), the Andalusī scholar and courtier of the Hafșids in North Africa, is sometimes mentioned as discussing Islamic civilization. He wrote about al-‘umrān al-basharī, "human cultivation," which Rosenthal and others have translated as "civilization"-not incorrectly, in one sense of the English word. See Ibn Khaldūn, al-Muqaddima, ed. M. Quatremère (Paris: Benjamin Duprat, 1858), 1:68; F. Rosenthal, trans., The Muqaddimah, 2nd ed. (London: Routledge and Kegan Paul, 1967), 1:89. But Ibn Khaldūn distinguished varieties of human cultivation merely as divided into the sedentary and pastoral types (hadari and badawī), not as supernational entities in world history, nor as founded on religions such as his own (Islam). Ibn Khaldūn also distinguished between different types of government and between Arabs and non-Arabs, and identified other interesting factors in large-scale history, but he never once referred to Islamic civilization. His discussion of the nature of the caliphate is likewise not about a transnational unit of human society with a common "high culture" unique to it. His interest was in patterns of human society. 
arts and sciences..$^{5}$ In France, the term civilisation developed almost simultaneously with the English word. It had, in French, especially the connotation of manners, civility, and refined and prestigious forms of conduct. The German word Zivilisation was borrowed from French in the eighteenth century.

\section{Civilizations}

In these derived senses, civilization was a matter of degree. Society could be more or less civilized, and successful civilization meant progress toward less savage qualities. It was apparent to Europeans in the late nineteenth century, however, that different peoples of the world had developed differently from them. Therefore, authors began to identify distinctly different "civilizations," turning the concept into one that also admitted of plurality. In this way, during the nineteenth century, the word civilization gradually developed the capacity to a serve as a vague stand-in for the word nation, especially when a collective term for societies before the modern nation-state was needed. By the end of the nineteenth century, books were being published in English with titles such as Primitive Civilizations (London, 1894)-this one, by Edith Jemima Simcox, describing the economies of Egypt, Mesopotamia, and China in antiquity. This use of the term is intact today.

With these terminological developments in place, in the late nineteenth and early twentieth centuries the term civilization was adopted by thinkers seeking to account for all the major patterns of human history. A model for discussing world history had been set by G. W. F. Hegel (1770-1831), whose spiritual interpretation of history was expressed in his Vorlesungen über die Philosophie der Weltgeschichte (1837). In this work, Hegel sought meaningful mystical patterns in supranational historical movements. For him, however, civilization was still a matter of degree, though distinct, individual nations carried the torch in each consecutive stage of his fanciful master narrative of enlightenment. ${ }^{6}$

Race, nation, and civilization competed as subjects of different master narratives of history in the late nineteenth century, but civilization became especially widespread in the early twentieth century between the World Wars. Two historians stand out as most responsible for applying and popularizing the term as the key to global history in this period. In highly influential works, Oswald Spengler $(1880-1936)^{7}$ and Arnold J. Toynbee (1889-1975) both concocted what were in effect their own complete lists of the distinct civilizations of the world. These entities had their life cycles: birth, adolescence, maturity, and senescence. Spengler counted eight civilizations that were the outcome of progress to "high cultures." Toynbee counted nineteen civilizations in the world, not to mention the "abortive" and

5. For the preceding, see G. C. Caffentzis, "On the Scottish Origins of 'Civilization," in Enduring Western Civilization, ed. S. Federici, 13-36 (Westport, CT: Praeger, 1995). Johnson's dictionary uses "uncivilized” as a gloss for "brute."

6. A concise summary of Hegel's view on the role of Islam in history can be found in A. Hourani, "Islam and the Philosophers of History," Middle East Studies 3, no. 3 (1967): 206-68, at 245-46.

7. O. Spengler, Der Untergang des Abendlandes, 2 vols. (Vienna: W. Braumüller, 1918-22); English translation The Decline of the West (New York: Alfred A. Knopf, 1926-28).

8. A. J. Toynbee, A Study of History, 12 vols. (London: Oxford University Press, 1934-61). 
"arrested" civilizations that might have entered maturity but did not. The history of the world could be told in terms of the vigor of the spirit and special characteristics of these distinct civilizations and the factors at play in that vigor. Civilizations, once understood as separate entities, needed to be compared to understand what made the peoples of the world irreducibly different. Spengler and Toynbee did not invent this way of thinking, and their use of "civilization" was controversial, ${ }^{9}$ but they did make civilizations a vernacular framework for twentieth-century talk about the peoples of the world and their histories. By distinguishing separate civilizations, historians committed themselves to an attempt to determine their essential characteristics, which applied generally to each of their respective human participants.

For some historians, the use of "civilization" was anti-nationalist and therefore antifascist. Thus Werner Jaeger (1888-1961), the influential classical scholar, wrote in 1936 of "the disruption of Western civilization which we are witnessing, with the rise of the doctrine that culture and knowledge are nationalistic possessions, dividing group from group, rather than expressions of kinship binding the heirs of a common heritage into closer union." ${ }^{10}$ For Jaeger, who had just emigrated to the United States to leave the National Socialist regime behind, the Greek texts he taught were the educational key to a united "West," meaning Europe and its colonies of people of European descent. Other examples could be produced, but this suffices to indicate that the well-intentioned goal of transcending nationalism was one early motivation in the development of the study of a putative Western civilization. Today, that has backfired badly, as Western civilization has become a rallying cry for racism and bigotry similar to those that the idea of Western civilization was developed to oppose.

The assumption that such distinct, different civilizations existed was taken for granted by innumerable intelligent people who nevertheless have never succeeded in defining the term in a way that would bear convincing analytical utility. To this day, the term civilization has no sound analytical basis. It has been conveniently redeployed in incommensurate ways on ever smaller scales to dignify important subjects for those unfamiliar with them. For example, one encounters talk of the civilization of the Hittites (a people), or of Mesopotamia (a region), or of Islam (a religion). Civilizations are designated not by thoroughgoing argument, but for the convenience of the historian in defining an area of expertise to bear the weight of a master narrative.

9. See, for example, the reaction of P. A. Sorokin, “Toynbee's Philosophy of History," Journal of Modern History 12 (1940): 374-87, at 381: "His 'civilizations' are not united systems but mere conglomerations of various civilizational objects and phenomena (congeries of systems and singular cultural traits) united only by special adjacency but not by causal or meaningful bonds." Walter Kaufman was similarly skeptical about Toynbee. In "Toynbee and Super-History," Partisan Review 22, no. 4 (1955): 531-41, at 536-37, he wrote, "The question of how many civilizations there are is like asking how many sciences there are, and the question when a particular civilization originated is on a level with the query when art began. Worse still, the conceit that civilizations are not only individual entities but the only units which can be studied historically one at a time, without referring beyond them, is the height of naiveté." These kinds of criticisms of the category have seldom been heard in the study of Islamic civilization, which begins by taking it for granted.

10. W. Jaeger, "Classical Philology and Humanism," Transactions and Proceedings of the American Philological Association 67 (1936): 363-74, at 363. 


\section{The Study of Civilizations as the Historical Counterpart of Philology}

The alleged founders of the putative Western civilization, ancient Greek authors, never wrote of such a thing as Western civilization. The expression in this sense occurs in English only as early as the 1850s, growing widespread only in the late nineteenth century. Its spread coincided with changes in the curriculum of universities. As technological subjects and professional skills gradually displaced classical learning in higher education, German philologists of Greek and Latin led a new approach to the study of their texts: Alterthumswissenschaft, the science of antiquity. This approach required the rich contextualization of ancient texts with Realien, all the materials of ancient life known through archaeology, epigraphy, numismatics, ethnography, and any other possible method. The broadened scope of traditional Greek and Latin scholarship is exemplified by the monumental Realencyclopädie der classischen Altertumswissenschaft (first edition 1837-52, expanded version 1894-1980). Scholars of Greek and Latin were now poised to become teachers of general courses on "classical civilization" for students who were facing too many demands to learn Greek and Latin for themselves and for whom learning Greek and Latin alone were inadequate to understand "classical antiquity" in the awesome complexity now revealed through enormous scholarly labors. ${ }^{11}$ This was a highly successful approach that professionalized scholars of Greek and Latin. It was soon emulated by the Semitists, who invented "Islamic civilization" for the purpose.

\section{From Semitic Philology to Islamic Civilization}

Islamic civilization was likewise conceived as distinct and internally coherent before any analysis. The term itself, with the qualifier "Islamic," implies at least one other (Western) civilization, the assumption of which was the precondition of its existence. From its first conception, therefore, and still today, one of the central debates about Islamic civilization has been its definition and boundaries. As its frontiers were never adequately defined, an overriding early concern has been the determination of what Muslims received or adopted from other allegedly distinct civilizations, and what that says about the character of this alleged Islamic civilization and the mentality of its inhabitants. The early European pioneers of Islamic civilization addressed not just texts but the Realien of their contexts, following the approach of Altertumswissenschaft. Soon they shifted, however, from studying the historical transmission of cultural goods and ideas between supposed separate civilizations, and especially into Islamic civilization from prior civilizations, to making claims about such concepts as "the Muslim mind" or "the conscience of Islam." In doing so, they almost always ignored economic conditions and other material factors in the lives of the persons participating in these exchanges. Such transactions are, indeed, "exchanges" and "encounters" only when they are conceived as crossing the boundaries of civilizations, which historians have preconceived in the first place. In this respect, the concept of distinct civilizations is an impediment to critical historical thinking.

11. C. Winterer, The Culture of Classicism (Baltimore: Johns Hopkins University Press, 2002). 
The concept of Islamic civilization, also long designated as "Muhammadan civilization," evolved gradually in the wake of classical civilization. In the early nineteenth century, historians did not write about a Muhammadan civilization. Gustav Weil (1808-1889), for example, wrote a Geschichte der Chaliphen in five volumes (1846-1862), which was, true to its title, a history of the caliphs from Abū Bakr onward, based closely on the Arabic sources available to him. His Geschichte der islamitischen Völker von Mohammed bis zur Zeit des Sultans Selim (1866), dealing with the religion, culture, and politics of specific peoples, was aimed at a learned public but likewise was not intended to provide broad generalizations about the character of an Islamic civilization. Nineteenth-century Semitists, perhaps not surprisingly, relied rather on "Semitic" as their category, making race-a false concept made worse through instinctively drawn but spurious ties to the genealogy of language familiesthe subject of their master narratives. For the prodigious philologist and historian Theodor Nöldeke (1836-1930), for example, Islam (the religion) and the caliphs (its chiefs) formed the subject of a historical narrative, but not a topic about which he could generalize on the broadest scale. For him, the latter entity was "the Semitic race," which he addressed in a work for a popular audience; in this work he contradicted some of the negative assessments of the Semites current in his day. ${ }^{12}$ Gustave Le Bon (1841-1931) wrote his La civilisation des Arabes (1884) in a similarly racial vein: the book begins with an essay on the racial and psychological characteristics of the Arabs.

The Austrian ambassador and historian Alfred von Kremer (1828-1889) may have been the first real expert in Arabic texts to plant the seeds of the idea of a Muhammadan (Islamic) civilization rather than a national, Arab civilization. For scholars of his generation, race and civilization were blurred as categories. He generalized about the Muhammadan world in works such as Geschichte der herrschenden Ideen des Islams (1868) and Culturgeschichte des Orients unter den Chaliphen (1875-1877), conceiving of a Muhammadan civilization that had already experienced its decline after racial mixture diluted its vigor. In the latter work, von Kremer dedicated a chapter to the Volkscharacter of his object, which he begins by observing that Arab civilization had brought some of the highest cultural goods that the Semitic race had ever produced. These Semites were guided by lofty ideal characteristics that enabled them to do relatively great things, though the same ideals also made for their shortcomings. In this way, putative civilizations were evaluated for their contributions to humanity. This way of thinking remains common today, as one regularly reads arguments about the "contributions" of Islamic civilization. Such arguments remain entangled in the concept of the efflorescence and decline of distinct civilizations.

The earliest use of "Muhammadan civilization" that I can find in English is from 1877, by the Hungarian Orientalist Edward Rehatsek, who spent most of his life in Bombay, where he catalogued Persian and other manuscripts, administered state language examinations, and taught Latin and mathematics at the University of Bombay.$^{13}$ His use of the term makes

12. Compare his popular essay on "Some Characteristics of the Semitic Race" with his historical sketch, "Islam," from Muhammad to his own colonial time, both in Th. Nöldeke, Sketches from Eastern History (London: Adam and Charles Black, 1892), 1-20 and 60-106, respectively.

13. E. Rehatsek, Catalogue Raisonné of the Arabic, Hindoostani, Persian and Turkish MSS. in the Mulla Firuz Library (Bombay: Education Society's Press, 1873). 
for a revealing anecdote. He began his essay "The Reciprocal Influence of European and Muhammadan Civilization" by explaining that "nations" have "various phases" of existence, "their first developments, their vigour, and their decay," "compared with the three principal stages of human life, namely, youth, virility, and decrepitude." ${ }^{14}$ For Rehatsek, nation and civilization were nearly interchangeable, and civilization admitted of degrees-nations are more or less civilized. He listed as other examples of civilizations "Ancient India, Persia, Assyria, Babylonia, Rome, and Greece." Writing in colonial British India, he devoted his essay to the idea that "power, dominion, civilization, the sciences and the arts, have left the East and have migrated to the West, whence their powerful rays are again beginning to fecundate and to revive the lands of their birth."

However, the argument of Rehatsek's essay was preconceived by educated persons in the British imperial government of India. He originally wrote it in 1863 or 1864 in the hope of a monetary reward in response to a public announcement by the government that a cash prize would be given to the best essay on this very thesis:

Compare the influence of Greek learning on the Arabs, under the Abbaside Caliphs of Bagdad and the Ommyade [sic] Caliphs of Cordova, with the subsequent influence of Arabian learning on the reviving European mind after the Dark Ages; and from the comparison infer the probable influence which the mature intellect of Europe should exercise in its turn, now that it is once more brought into contact with the Muhammadan mind in India.

The essay was supposed to be written in the Urdu "of common conversation," indicating its purpose-to indoctrinate Indian Muslims about the cultural benefits of British rule, not many years after the great Indian Rebellion of 1857-1859. Rehatsek's essay merely elaborated and illustrated some arguments for the thesis already set by the prize offer, but it did so with "civilization," a term not found in the essay prompt. Although he wrote his piece in English and then translated it into Persian, not Urdu, for submission, a government committee led by William Muir (1819-1905), the Scottish historian of the caliphate, nevertheless awarded the prize to Rehatsek's essay, leading to its eventual publication. It was, after all, only one of two submissions for the prize received in Calcutta. One of the judges, a certain Muhammad Wajih, wrote in assessment, "I agree with this Report [namely, the approval of the essay by Muir], but some portions of the Essay are contrary to the tenets of Islam, are irrelevant to the question, and are not true." Hilariously, but in all fairness, this statement accompanied Rehatsek's essay in the printed version. The essay seems to have had little influence, but it demonstrates, along with von Kremer's publications, that "Muhammadan civilization" was an idea in its infancy in the 1860s. Soon scholars like Ernest Renan (1823-1892) would write essays on the character of this civilization, understood in such terms. ${ }^{15}$

14. E. Rehatsek, Prize Essay on the Reciprocal Influence of European and Muhammadan Civilization during the Period of the Khalifs and the Present Time (Bombay: Education Society's Press, 1877), 1.

15. E. Renan, L'islamisme et la science (Paris: Calmann Lévy, 1883). 
Collaborating Semitists, familiar with works such as those of von Kremer, conceived of an Oriental encyclopaedia that could be the eastern counterpart to the Realencyclopädie der classischen Altertumswissenschaft, discussing the project in 1892 at the Ninth International Congress of Orientalists in London. Its prospective range was immediately delimited in that meeting as "Arabic-Muhammadan." 16 This is one of the clearest early instances of the collocation of the two topics in the still-living designation "Arabic and Islamic studies." After much planning and effort, the outcome was The Encyclopaedia of Islam (first edition 1913-1938). Ultimately, Islamic civilization became widespread through the attempt by Arabic specialists, who were Semitic philologists by training, to imitate for their materials what classical scholars had done for their own. Whereas classical scholars had a "classical civilization" to frame their investigations combining Greek and Roman antiquities, Semitists used "Muhammadan civilization" to give historical meaning to Arabic philology. It also facilitated their inclusion of Persian and Turkish along with Arabic, dividing Semitic studies henceforth into two trajectories, ancient and Islamic. ${ }^{17}$ The mastery of the three "Islamic" languages became an ideal very rarely attained, for practical reasons. In any case, Arabic and Islamic studies became an entity as tightly bound as Greek, Latin, and Classical studies. Islam specialists gradually ceased to study comparative Semitic linguistics.

As preparation was underway for The Encyclopædia of Islam, scholars continued to broaden the conceptual Kulturkreis of Islam. ${ }^{18}$ Around the turn of the century, it became normal for scholars to write about Muhammadan civilization. The concept was adopted in Arab countries now, too: von Kremer's and Le Bon's work informed the Lebanese scholar Jurji Zaydan (1861-1914), who used the term "Islamic" rather than "Arab" in his Tārīkh al-tamaddun al-islāmi (History of Islamic Civilization, 1901-1906) while he worked at the Egyptian University.

In 1910, Carl Heinrich Becker (1876-1933), a German scholar and politician, founded the journal Der Islam and wrote the first article of its inaugural issue, "Der Islam als Problem," a kind of manifesto for Islamic studies. He argued, in the vein of von Kremer, that Islam was not just a religion but also an empire and a political theory. These factors, combined, made Islam into a unitary civilization (Einheitszivilisation) that, despite local variations, bore a uniform imprint in every place of its existence. ${ }^{19}$ This clearly articulated view is still being repeated today. No matter the country, the century, the ecology, the economy, the customs, or the language, Islamic civilization is supposed to taste the same wherever one finds it. The next year, 1911, saw the first issue of The Moslem World, published by the Hartford Seminary. In the opening editorial of the journal, Rev. S. M. Zwemer noted the new periodical Der Islam and the forthcoming Encyclopaedia of Islam and insisted that there

16. P. Bearman, A History of the "Encyclopaedia of Islam" (Atlanta: Lockwood Press, 2018), 1.

17. This was just the kind of change called for by the fiery Martin Hartmann in 1898, in favor of a new field of Islamic studies: "Die Arabistik: Reformvorschläge," Orientalistische Literaturzeitung 1 (1898): 333-42. Cf. M. Kramer, "Arabistik and Arabism: The Passions of Martin Hartmann," Middle Eastern Studies 24, no. 3 (1989): 283-300, at 286.

18. The Austrian ethnologist Leo Frobenius published the concept of "cultural area" in 1898.

19. C. H. Becker, "Der Islam als Problem," Der Islam 1 (1910): 1-21. 
should be a journal that contextualizes matters Islamic "as they affect the Church of Christ and its missionary programme." ${ }^{20}$

The first edition of The Encyclopaedia of Islam: A Dictionary of the Geography, Ethnography and Biography of the Muhammadan Peoples, published in English, French, and German versions, corralled the world's leading scholars of Arabic and Islamic studies into an enterprise in which the basis of collaboration was Islamic civilization. The monumental outcome remains an extremely useful tool of scholarship and a compendium of vast learning. Scholars' shared participation in this effort made the expression "Islamic civilization" common currency internationally. The ideas expressed by Becker were now adopted widely. For example, Edward Granville Browne (1862-1926), Sir Thomas Adams's Professor of Arabic, in his 1921 monograph Arabian Medicine, explicitly prefers "Muhammadan" civilization to "Arabian" ("more correctly," he says), though Arabic was the chief language of learning in this civilization and bound it together. ${ }^{21} \mathrm{He}$ was on the steering committee for $E I$ at the time.

With at least two journals and an encyclopedia of its own, Islamic civilization had become, by the onset of the First World War, a framework common to formerly separate strands of scholarship. It was, however, still a domain of discussion for specialist philologists, not for social scientist generalists.

\section{Islamic Civilization Migrates to the United States}

In the wake of the Second World War, Arabic scholars in the United States began to write in earnest about the general essential characteristics of an Islamic civilization. Two events promoted this turn. One was the emigration of Semitists specializing in Arabic to the United States, as the National Socialist regime endangered their prospects for life in Europe. They brought with them the framework of Arabic and Islamic studies, in which the two terms represented the philological study of the main source language and the historical approach to the corresponding "civilization," respectively. The other event was the rapid growth of the American university and the development of new curricula to meet the new educational demands of postwar American society. In this setting, the General Education movement sought to reorganize liberal arts and sciences education to avoid both exclusive specialization and the transformation of universities into technical colleges.

The roots of the General Education movement were closely tied to efforts by the US State Department to equip Americans, and especially military personnel, with knowledge of the European nations among which and for which Americans would fight. Understanding a common civilizational heritage was explicitly meant to build morale. Columbia University's mandatory "Contemporary Civilization" course-originally entitled "War Issues"-was developed specifically in response to a request from the State Department in 1917 to train future soldiers. Though it was first offered only in 1919, after the war's end, it became a model in American higher education. "Western civilization" thereafter became not just a concept for organizing and integrating classical studies and the history of European

20. S. W. Zwemer, “Editorial,” The Moslem World 1, no. 1 (1911): 1-4, at 2.

21. E. G. Browne, Arabian Medicine (Cambridge: Cambridge University Press, 1921), 4 and 6. 
culture but an institution of formally organized courses required for certain university degrees at various universities. ${ }^{22}$ Once enshrined in an authoritative educational institution, iterated annually, the Western civilization concept more easily took on the character of a widespread, socially shared belief.

The General Education movement became pervasive in the United States in the 1940s during the next great war. In 1943, the president of Harvard University created a committee that produced, two years later, a book-length thesis, The Objectives of General Education in a Free Society (Harvard University Committee, 1945), published "with the compliments of the Department of State of the United States of America." This document became standard reading and remains an underlying template for American higher education in the liberal arts and sciences. The model explicitly offered an educational prescription for freedom and democracy against totalitarianism. The ideological charge of the plan reflects its preparation in a time of devastating global war. It is underpinned by the belief that Western civilization needed to be defended against antitraditional forces, which emerged into focus as fascism and communism. Western civilization was also used beyond higher education as a rationale for US patronage of countries seeking to "develop" with US aid and anticommunist intervention.

Although "Western Civilization" courses first took root at Columbia, "Islamic Civilization" survey courses were launched at the University of Chicago. General education was the motive; a European Semitist was the initiator; and a dean who had studied at Columbia during the onset of the Contemporary Civilization curriculum was one of the main instigators. The outcome of this new trend was to create an educated nonspecialist public that believed in the existence of an Islamic civilization.

One of the leaders of the General Education movement was Richard McKeon (1900-1985), professor of philosophy at the University of Chicago from 1934 and dean of humanities there from 1940 until 1952. McKeon finished his bachelor's in 1920 at Columbia University, a year after the inception of the Contemporary Civilization model. He wrote in 1949 in the new Journal of General Education (which had been launched in 1946), at the time published by the University of Chicago Press, that the postwar "present age" required an education imparting a global outlook and promoting cultural understanding to reduce conflicts everywhere. "The Western Tradition or the Civilization of Western Europe has taken its place in a context of world civilization and world cultures. . . . Oriental cultures, which influenced the West in past periods, are now not influence but part of the contexture of world civilization." ${ }^{23}$ These cultures required, therefore, special courses of study available to the generality of university students. The plan was carried out over the next few years.

At that time, McKeon was a supervising dean of the Austrian scholar Gustave von Grunebaum (1909-1972). Von Grunebaum had emigrated to the United States in 1938 upon the annexation of Austria by Germany and in 1943 had joined the faculty of the University

22. S. Federici, "The God That Never Failed: The Origins and Crises of Western Civilization," in Federici, Enduring Western Civilization, 63-89.

23. R. McKeon, "The Nature and Teaching of the Humanities," Journal of General Education 3, no. 4 (1949): 290-303, at 292-93. 
of Chicago, where he became professor of Arabic in 1949. He would go on to be a major organizer of European-style "Arabic and Islamic studies" in the United States. In the issue of the Journal of General Education immediately following that in which his dean, McKeon, made the case for fostering the study of Oriental civilizations in the general requirements of every college student, von Grunebaum published an article on the role of "Islam in a Humanistic Education." ${ }^{24}$ Though meandering and diffuse, this article responded to McKeon's call.

Von Grunebaum's Medieval Islam: A Study in Cultural Orientation, which was based on public lectures delivered at Chicago in 1945, had been issued by the University of Chicago Press in 1946. It was probably used in instruction there; in any case, it sold enough copies that the first edition was printed again in 1947. The book treats Islamic civilization as an entity long past its prime-hence the qualification "medieval" in the title-and debates the contrast between the apparent "picturesque uniformity of Islamic civilization" and its "inexhaustible diversity behind the colorful veil." ${ }^{5}$ Muslim civilization, for von Grunebaum, was both composite and uniform as well as self-contained. Believing he understood the synthesis arising from its ingredients, he could declare that "the strength of Islam is in the roundedness of personality which at its best it is able to produce," ${ }^{26}$ along with other similarly dubious generalizations. Von Grunebaum, whose early specialty was Arabic poetry, believed that "Muslim civilization's contributions to man's spiritual life were offered on the verbal level," or, in other words, appeared in the texts that he himself happened to know. ${ }^{27}$ The conviction that Islamic civilization had peculiar, pervasive, general characteristics wherever it took root, out of which sense could be made, was fundamental to von Grunebaum's role in promoting this subject.

Not everybody was happy with the way Islamic civilization was developing as a topic. Franz Rosenthal was another Semitist emigrant from Germany to the United States. As a Jew, he had escaped death at the hands of the National Socialist regime. In the introduction to his source-based monograph of 1947, The Technique and Approach of Muslim Scholarship, written when he was on the faculty of Hebrew Union College in Cincinnati, he referred to "the highly debated subject of the general character of Muslim civilization." He confronted the views of scholars from Hegel to von Kremer and found them mutually inconsistent. By adhering to the method of recovery and analysis of primary resources, Rosenthal held, "(i)t might then be possible to avoid distortions of the picture of Muslim civilization such as result from ill-advised generalizations." Here he explicitly had Hegel in mind. ${ }^{28}$ It is not clear whether he had read von Grunebaum's Medieval Islam at this time, but decades later, in his obituary of von Grunebaum, with whom he had often had lunch in the summer

24. G. von Grunebaum, "Islam in a Humanistic Education," Journal of General Education 4, no. 1 (1949): $12-31$.

25. G. von Grunebaum, Medieval Islam (Chicago: University of Chicago Press, 1946), 320.

26. Ibid., 346.

27. Ibid., 258.

28. F. Rosenthal, The Technique and Approach of Muslim Scholarship (Rome: Pontificium Institutum Biblicum, 1947), 4. 
of $1942^{29}$ and whom he certainly knew from other occasions, Rosenthal would briefly pay compliment to the book as a "standard work of synthesis of the cultural history of Islam." 30 Rosenthal's own major publications were likewise based on the assumption that a distinct Muslim civilization existed, fundamentally different from the Western civilization though closely intertwined with it. His approach was historical, based on primary sources, and more cautious, but he, too, offered generalizations from time to time about Islamic topics with monographs such as The Muslim Concept of Freedom (1960) and Das Fortleben der Antike im Islam (1960). Yet in his 1947 Technique and Approach he wrote, "General statements about civilizations which are as complex and far-flung as Islam usually turn out to be little satisfactory, especially after some time has elapsed and scholarly trends have changed." ${ }^{11}$ These words have turned out to be true still today.

A more revealing and pointed reaction to the model of Islamic civilization, which had no echo, was offered by the orientalist Vladimir Minorsky (1877-1966). Von Grunebaum, his junior by more than three decades, had invited Minorsky to deliver a presentation at a 1953 conference entitled "Unity and Variety in Muslim Civilization" at the University of Liège, Belgium, cosponsored by the University of Chicago. Many leading European scholars participated. The title itself reveals the dilemma in accepting a category such as Islamic civilization, even as it insists that the topic is real. Von Grunebaum presented the keynote address and edited the proceedings, published by the University of Chicago Press (1955). In his address he insisted that Islamized peoples are essentially changed into a uniform Islamic type. ${ }^{32}$ Minorsky, however, stated at the outset of his contribution that he found the very theme of the conference problematic. He remarked that this is because "the present tendency is rather to treat separately the history of the Arab, Iranian, and Turkish lands and peoples, as we treat the history of the European peoples regardless of the fact that in the Middle Ages they recognized the same authority of the church, and used the same Latin and the same canon law." (He should have said "the earlier tendency was.") The answer he offered to the dilemma was to take a historical approach to the study of Islam in Persia and tacitly to avoid generalizations about discrete civilizations. At the end of the paper, he directly criticized the approach of von Grunebaum, the editor of the volume, for his judgmental stance on the personality and character of Persians occurring in his book Medieval Islam. Minorsky insisted that the characteristics von Grunebaum attributed to them, such as duplicity and emotionalism, had to be understood as products of historical events-specifically, the experience of repeated subjugation by foreign invaders. "One must not speak," he wrote, "of Islâm and its subdivisions as if these were logical and absolute categories." Minorsky's attitude reflects an earlier phase of Oriental research, in which the

29. H. H. Biesterfeldt, ed., "Franz Rosenthal's Half an Autobiography," Die Welt des Islams 54 (2014): 34-105, at 71 and 75.

30. F. Rosenthal, “In Memoriam: Gustave E. von Grunebaum," International Journal of Middle East Studies 4, no. 3 (1973): 355-58, at 357.

31. Rosenthal, Technique, 4.

32. G. E. von Grunebaum, "The Problem: Unity in Diversity," in Unity and Variety in Muslim Civilization, ed. G. E. von Grunebaum, 17-37 (Chicago: University of Chicago Press, 1955). 
subjects of history were not supranational, internally uniform "civilizations" but nations (an older conceptual unit) and the individuals in them and the works they wrote. Minorsky's explicit discomfort with Islamic civilization shows that addressing it was still novel to many, even though Minorsky had contributed amply to the Encyclopaedia of Islam. He was certainly willing to condone character generalizations regarding nations, but he demanded an explanation for them in terms of changing historical conditions. ${ }^{33}$

It is impossible to know whether other European historians of Islam, such as Ignaz Goldziher (1850-1921), refrained from using the concept of Islamic civilization because they objected to it or because they were simply uninterested in it, but many historians readily and increasingly accepted Islamic civilization as a valid concept without opposition. The historian Philip Hitti (1886-1978), for example, could casually endorse the idea in 1956 in his review of the conference proceedings volume just mentioned, stating that Islamic civilization was "one of the five or six major civilizations of the world." ${ }^{4}$ Earlier in his career, while a professor at Princeton, he had written his History of the Arabs (1937), which was essentially a history from Muhammad to the present, covering what is generally known today as the history of Islamic civilization but focusing on "the Arabs." The work was widely read. By 1970, when that earlier book was entering its tenth edition, he published a new work entitled Islam: A Way of Life. It argues that "Islam" is not just a religion but simultaneously a state and a culture. The subject of the master narrative had changed from the Arabs to Islam, and the latter was more than merely a religion. Already sixty years earlier, Becker had articulated the same idea, and before Becker, von Kremer.

Chicago was, of course, not the only site at which scholars offered unfounded generalizations about the alleged Islamic civilization. Civilizations became a major topic in the early to mid-twentieth century. In the 1930s, Reuben Levy, professor of Persian at the University of Cambridge, expressed in the preface to his two-volume The Sociology of Islam (1931-1933, reprinted in 1955, as the structural anthropology of Claude Lévi-Strauss became current, with the title The Social Structure of Islam), that "the Muhammadan communities of the world, possessing certain common characteristics traceable to the religion, are suited for treatment as a unity." 35 Though von Grunebaum and others used and cited this work of Levy's, it was von Grunebaum's student and successor who made Islamic civilization into a general educational institution of practice.

\section{Hodgson and the First General Education Undergraduate Islamic Civilization Course}

The issues sketched above were central in the field in which Marshal Hodgson (1922-1968) received his education. Hodgson was von Grunebaum's doctoral advisee at the University of Chicago, where he received the $\mathrm{PhD}$ in 1951 as part of the first graduating

33. V. Minorsky, "Iran: Opposition, Martyrdom, and Revolt," in von Grunebaum, Unity and Variety, 183-206; reprinted (with the title that Minorsky originally chose) as "Persia: Religion and History," in V. Minorsky, Iranica: Twenty Articles, 242-57 (Tehran: University of Tehran, 1964).

34. P. K. Hitti, review of von Grunebaum, Unity and Variety, in American Historical Review 61, no. 4 (1956): 931-32.

35. R. Levy, The Social Structure of Islam (Cambridge: Cambridge University Press, 1957), 1:v. 
class of the doctoral program of the transdisciplinary Committee on Social Thought. He shared his teacher's preoccupation with the problem of unity and diversity in Muslim civilization. It may be true, as a recent New York Times Magazine article states of him with a whiff of hagiography, that "Hodgson devoted his professional life to correcting the errors of the Orientalists," ${ }^{6}$ but he also accepted the frame of reference in which they worked-Islamic civilization-and many of the assumptions that a such a premise confers. Von Grunebaum must have been involved in hiring Hodgson to the Chicago faculty in 1953, soon after his completion of the doctorate. The same year saw the appearance of the second edition of von Grunebaum's Medieval Islam from the University of Chicago Press. When von Grunebaum left the University of Chicago in 1957 to join UCLA and play a founding role in the Center for Near Eastern Studies there, Hodgson filled von Grunebaum's part in teaching Islamic civilization at Chicago. But whereas von Grunebaum was teaching Islamic civilization as a part of the humanities, Hodgson's task was to make it part of the general education curriculum of social sciences at Chicago.

The University of Chicago inaugurated the first required "non-Western civilization" courses in 1956, after two years of committee meetings and discussions about their advisability and feasibility. As a quartet of articles published in the Journal of General Education-still issued by the University of Chicago Press-in 1959 explains, three non-Western civilization courses were created, rather than a single yearlong "Oriental civilizations" course such as existed already experimentally at Columbia University. China, India, and Islam were the three "civilizations" chosen. The rationale for this new curricular development was explained by Milton Singer, who had been one of the organizers of von Grunebaum's conference in Liège. He summarized the recommendation of the faculty committee at the University of Chicago:

The committee believed that such study [of non-Western civilizations] would not only "familiarize the student with a civilized tradition other than his own, and thus permit him to glimpse the world and his own civilization as others see them," but would also "enable him to understand better his own cultural heritage by comparing it with another." Such study, it hoped, would "offset the almost exclusive emphasis upon study of the society and culture of Europe and the United States which currently prevails in the College and most Divisional courses." ${ }^{37}$

Marshall Hodgson, still an assistant professor, contributed one of the accompanying journal articles to explain the rationale of a yearlong Islamic civilization course that would satisfy the new non-Western civilization requirement in the social sciences. ${ }^{38}$ His explanation is

36. L. Kiesling, "Letter of Recommendation: The Life of Marshall Hodgson," New York Times Magazine, October 6, 2016, https://www.nytimes.com/2016/10/09/magazine/letter-of-recommendation-the-life-ofmarshall-hodgson.html.

37. M. Singer, “Chicago's Non-Western Civilizations Program,” Journal of General Education 12, no. 1 (1959): 22-23.

38. M. Hodgson, "A Non-Western Civilization Course in a Liberal Education with Special Attention to the Case of Islâm," Journal of General Education 12, no. 1 (1959): 39-49. 
clear and rational, and it expresses the hope for high enough enrollment to justify hiring more faculty to teach it.

Hodgson offered the first such course, beginning in the autumn academic quarter of 1956. This is the first instance in which Islamic civilization was offered as a course fulfilling a general requirement (rather than as a special elective topic) for an undergraduate degree, at least in the United States, and it may fairly be regarded as the beginning of Islamic civilization as a regular institution. It would henceforth recur annually. To this day, the yearlong Islamic History and Society course sequence can fulfill the Civilization Studies component of the Core general education requirements in the College of the University of Chicago (though there are now many other such civilization courses in competition with it). Chicago was only the first of many sites at which Islamic civilization took root in a robust institution. Many other universities have followed the practice. "Non-Western civilization" requirements have become and remain common in American universities and colleges. Islamic civilization has spread as a feature of institutions of higher education.

The three volumes of Hodgson's posthumously published The Venture of Islam correspond to the three quarter terms of the regular academic year in which he taught this survey at the University of Chicago. His article of 1959 ends with an outline of the yearlong course's topics. These topics were reflected in the prototype of his Venture of Islam, issued by the University of Chicago Press for his course in 1958-1959 under the title Introduction to Islamic Civilization: Course Syllabus and Selected Readings, likewise in three volumes. The problem that confronted Hodgson was how to organize the narrative of an entire alleged civilization to yield the greater, moral lessons demanded by a general education. Hodgson believed that Islamic civilization should not be the domain of specialists alone, and he saw that instruction of undergraduate students in the history of Islamic civilization was a way to promote the project of history in general and world history in particular.

\section{Islamicate Civilization}

In The Venture of Islam, Hodgson was explicit that his interest was in "civilization studies," which he glossed as "the study of the great cultural heritages." Unlike most of his predecessors, he attempted to define clearly what a civilization is, and he did so with great earnestness. In the face of the incommensurability of the civilizations already accepted at large ("Islam," "the West," and others), he concluded that "the reason for distinguishing a civilization cannot be a single, universal one"; rather, "it must almost be special to each case." This is to say that each civilization must be defined by its own criteria-which, logically, should mean that civilization is not a category of analysis but the vague product of subjective judgment. Nevertheless, Hodgson wanted a civilization to refer to "any wider grouping of cultures in so far as they share consciously in interdependent cumulative traditions." By this he meant "major lettered traditions." ${ }^{39}$ In this concession one hears echoes of von Grunebaum.

In his teaching and research, Hodgson wrestled with the problem articulated as long ago as by Edward Rehatsek in 1877, when Muhammadan civilization was a new idea. How

39. M. Hodgson, The Venture of Islam, 3 vols. (Chicago: University of Chicago Press, 1974), 1:22. 
can the religion of Islam alone characterize innumerable societies that differ in every way and that contain many non-Muslim people and many things not concerned with religion at all, not to mention the many varieties of Islam? How can scholars insist on a single Islamic civilization when there is infinite variation among Muslim peoples in every human dimension? What distinguishes Islamic civilization from other civilizations when there is a constant exchange evident between them and the boundaries are always blurry? "Islamicate" was the term Hodgson proposed to rectify the problem. The neologism is formed by analogy with English words derived from Latin passive participles to signify that which is made to be or construed as Islamic rather than being so essentially. That is, Islamicate was supposed to refer only to the quality of belonging to Islamic civilization without claiming that the thing to which it applies is essentially a feature of Islam. It was a term, therefore, intended to be intellectually honest about the explanatory limits in calling something Islamic within the context of Islamic civilization. Yet the problem inherent in Islamic civilization remained even after the adjective was changed because it remained an undefined civilization. Moreover, in hindsight it is clear that Hodgson was already trained and bound to teach Islamic civilization by his career at the University of Chicago. It was a professional responsibility that he had inherited. It was a framework that he made highly effective for teaching the history of the "medieval" and "early modern" Middle East in a way that was meaningful for twentieth-century college students. He recognized that Islamic civilization as a category was not sufficient, but instead of throwing out the category on which his place in the curriculum was based, he concluded that new terminology was required for blurrier distinctions. "${ }^{40}$ "Islamicate" offered a way to continue teaching an ill-defined subject while acknowledging that ultimately it made little sense unless one ignored a vast amount of meaningful complexity. Certainly, Hodgson understood the degree of complexity involved, but he wanted not to abandon Islamic civilization. We can only assume he believed his own argument about the unity of Islamic civilization, which he had heard from von Grunebaum and read from Becker and many others. The term "Islamicate" was therefore an awkward compromise as it is an awkward neologism, albeit one that is now, in the twenty-first century, widely employed as a term of art.

\section{Painting the Field into a Corner}

The palatable model of an Islamic civilization course in the framework of non-Western civilization curricula, widely emulated, seems to have generated a demand for university instruction about life and history in a broad region of the earth hitherto neglected by the European and American academy. It helped to create a thriving field of scholarship. Islamic civilization became a popular subject. At the same time, Islamic civilization, being conceived as a unitary object of investigation, Becker's Einheitszivilisation, also set a tight limit on the institutional growth of the field. Islamic civilization was an economical model for university administrations: history departments or religious studies departments at colleges and universities that developed "non-Western" or "global" general requirements for their students could apparently satisfy the need to cover all of Islamic civilization,

40. Hodgson, Venture, 1:57-60. 
across continents and over fourteen centuries, by hiring one specialist in that unitary field. These prospects were a vast improvement over the situation in 1955, when the Asia Society found only seven American institutions offering regular undergraduate instruction on Asian civilizations. ${ }^{41}$ Now every self-respecting university required one such expertjust one, who could teach Islamic civilization for undergraduates. Graduate programs that trained Near Eastern language specialists responded to the new market in "Non-Western Civ" courses by granting more PhDs to individuals taught to use Arabic sources who could survey this unitary civilization in courses for undergraduates. The claim to be able to explain all this material to college students was a professional requirement: positions were created specifically for instruction in Islamic civilization. Arabs, Iranians, Turks, and other subjects of the past and present had to crowd into a single classroom under the umbrella of a grand narrative unified by a single religion to the exclusion of other salient factors. Those called to teach Islamic civilization by job description understandably provided the requisite master narrative that explained the area of expertise for which they were employed. Again, the wider availability of instruction on Islam and Middle Eastern societies was an enormous gain for higher education. At the same time, the encompassing moral vision of a unitary Islamic civilization has stunted the potential for increased numbers of professional scholars making sense of the complex history of cultures bearing distinct differences. While the most powerful nations of Europe and America can, as fields of study, demand specialist professors devoted to them individually at a large institution of higher education-sometimes multiple professors for one country-the entirety of Islamic civilization, from the seventh to the twenty-first century and from the Atlantic to the Pacific, usually gets one, or often at best one per relevant disciplinary department.

The master narrative of Islamic civilization thus first entrenched but then restricted the intellectual and professional interests of the scholars hired to promote it with limited resources. Their development of the vision of a whole essentially religious civilization, in turn, has granted authoritative scholarly legitimation to those seeking ideological and political power in the world around them in terms of Islam. Some of these individuals used the European scholar's concept of Islamic civilization as a platform for social influence in the name of the religion of Islam, thanks to the supranational and essentially religious "civilization" it has been granted by putatively neutral outsider experts. Apologists and those using the religion of Islam as a vehicle of social power adopted the Orientalists' fundamental concept and cherry-picked the latter's research for elements that suited their personal and anti-historical political agenda, rejecting the rest as "Orientalism" (in the negative sense promoted after Said's 1978 book Orientalism). ${ }^{42}$ Others wished to detract from and stigmatize a generalized Islamic civilization in the name of political policies or even furtive racial and national bigotry of different varieties. Bernard Lewis

41. W. Morehouse, "Asian Studies in Undergraduate Education," Journal of General Education 11, no. 3 (1958): 125-40.

42. On this book and its impact, see Z. Lockman, Contending Visions of the Middle East: The History and Politics of Orientalism, 2nd ed. (Cambridge: Cambridge University Press, 1999). 
(1916-2018) famously invoked the notion of a "clash of civilizations" (1990), ${ }^{43}$ which became the title of a book (1996) by political scientist Samuel Huntington (1927-2008). Huntington's book developed a neo-Spenglerian concept of inter-civilizational struggle, imagining nine distinct civilizations in the world at the end of the twentieth century, each basically rooted in a religion, such as Islam. Social scientists affirm or deny Islamic civilization, sometimes with pseudoscience. ${ }^{44}$ Islamic civilization forms a unitary target for polemicists as much as it does a unitary platform for apologists. Donors participate, too, with various intentions, by creating endowments and academic positions for the study of Islamic civilization. The well-meaning goal of dignifying present people resorts to myths of a glorious past, even though respect for humans living in the present, in my view at least, should never depend on their cultural, ancestral, or genetic lineage. Government entities devote funds to Islamic civilization, generating events that prolong its existence and give it a shared social reality, however nebulous and debated its definition. Now Islamic civilization exists well beyond the writing of Arabic specialists. It has more money behind it than ever before. Historians no longer create it; they serve it.

\section{Beyond Islamic Civilization?}

Most scholars who employ Islamic civilization and teach courses about it are sincerely attempting to create knowledge and foster understanding about an important part of human history. Among them there have been a few who have reflected critically on Islamic civilization. As long ago as 1973, Roger Owen (1935-2018) called for a reexamination of

the assumption that the basic unit of study remains something called "Islamic civilization." Until this is done, the subject will continue to be handicapped. . . . [One way in which this occurs is through] the imposition of an artificial unity upon a world spreading from Morocco to Indonesia, thus making what it is that the societies of this area have in common far outweigh that which divides them. . . . The assumption that [Islam] provides the essential ingredient in a complex chain of societies stretching across Africa and Asia may now be acting to encourage the writing of bad history and to prevent the emergence of something more worthwhile.

Owen added that "even such a limited program of reexamination will surely be resisted." 45 The expectation of resistance conveys the extent to which Islamic civilization had become entrenched by the 1970s. But the program of reexamination was not resisted because it never arrived. Islamic civilization has continued to grow through the annual reiteration of college courses, journals, and events, as well as book series and other material manifestations of Islamic civilization. In short, Islamic civilization acquired institutions when it was a preeminent model, in the mid-twentieth century, becoming embedded in curricula connected with specific faculty positions. Institutions are resistant to change.

\footnotetext{
43. B. Lewis, "The Roots of Muslim Rage," Atlantic, September 1990.

44. E.g., Y. Esmer, "Is There an Islamic Civilization?," Comparative Sociology 1 (2002): 265-98. (The answer offered, based on absurd criteria and numbers derived from personal surveys, is "yes.")

45. R. Owen, "Studying Islamic History," Journal of Interdisciplinary History 4, no. 2 (1973): 287-98.
} 
Despite occasional conferences revisiting the topic and questioning the relevance of Islamic civilization, like the one at which I first presented part of this paper, its institutional existence and its common currency have made it into a convenient default for both instruction and discussion. Moreover, humanistic scholars, social scientists, proponents of Islam, and antagonists of Islam share a common interest in promoting Islamic civilization. A unitary Islamic civilization facilitates a master narrative intended to persuade and greatly simplifies analysis and argument through generalization without evidence. Islamic civilization makes it easy for all these participants to justify what they were already doing, and so it is not likely to disappear.

All the objects of Islamic civilization deserve scholarly research and understanding. But is there an alternative to Islamic civilization for these objects? Is it possible to move beyond Islamic civilization's ill-posed inherent question about unity and diversity? The analytical utility of this civilization remains doubtful now as it was before. Recognizing this, specialists continue to posit modified, hybrid, and rationalized Islamic civilizations, sometimes using different terminology for the same effect. ${ }^{46}$ Even if Islamic civilization foundations and journals keep their names, can historians abandon Islamic civilization and enhance their analysis? Some years ago, I expressed these ideas to an eminent senior colleague in Near Eastern studies, whose specialty was Islamic history. She nodded and seemed to agree but then asked, "So if there is no Islamic civilization, what do you call it?" My answer was that there is no "it." The matter is rather as Hodgson himself explicitly stated: "There are many ways of grouping into 'civilizations' what is in fact an endless chain of interrelated cultural life. We must know why we make the selection we do." ${ }^{47}$ Yet his selection was determined by the academic position he held and the curricular opportunity he saw to promote knowledge and human understanding on a wide scale-a laudable goal. Any criterion may have sufficed because Islamic civilization was already assumed. It is like the essay prompt answered by Rehatsek for cash in the 1860s. Today's scholars usually do not know why they still make this selection. It is just how we were taught. The myth of its origins in the seventh century promotes the sense that Islamic civilization existed before analysis.

Hodgson's assumption that we need to group the endless chain of interrelated cultural life into civilizational categories-a convenient way to explain all history in broad brushstrokes-still has its most important manifestation in the curricula we teach today. Sometimes broad brushstrokes are useful and necessary. But we must ask whether our histories of the Middle East and other regions will make sense without Islamic civilization. If our histories do make sense without Islamic civilization, why do we continue to use it? But if they do not make sense without Islamic civilization, then how valid can our histories be when Islamic civilization has no accepted definition, having become pervasive solely as an accident of recent European colonial history and postwar developments in American university curricula? Can professional historians of Muslims or Middle Eastern peoples find

46. E.g., R. Bulliet's The Case for Islamo-Christian Civilization (New York: Columbia University Press, 2004), a response to the World Trade Center attacks in 2001. S. Ahmed, in What Is Islam?, rejects Hodgson's Islamicate civilization but defines Islam itself in very nearly the same terms, connecting it with adab and literary culture.

47. Hodgson, Venture, 1:91. 
other ways to make sense for an educated public and to convey relevant educational lessons for college students out of the humans of the past and present whose lives they study? Or is Islamic civilization still adequate for what it was supposed to do in the classroom, even now when its existence is widely interpreted to mean that Muslims are irreducibly incompatible with others?

One might suppose from this essay that I think that Islamic civilization courses should come to an end. To me, this does not precisely follow. We often use artificial terms of wide currency for the sake of convenience. "The Middle East" is one such term; 48 "medieval" is another. ${ }^{49}$ Such expressions have peculiar histories. There are scholars of "the medieval Middle East" and "medieval Islamic civilization." Whatever terms one uses, the religion of Islam and the peoples of the Middle East and other regions in which Muslims predominate require study and understanding. Yet we should know why we use the terms we do use, what they were devised to address, what they assume, and who benefits from them, lest we rely on them to the point that they misguide us. There are other ways to organize knowledge about Muslims and the countries Muslims have ruled. Islamic civilization is only one possibility. Its use conditions the questions one asks and the answers one gives while deferring questions never considered, but both the questions and the answers are symptoms of our time and our society, not of most other times and places.

48. R. Adelson, "British and U.S. Use and Misuse of the Term "Middle East," in Is There a Middle East? The Evolution of a Geopolitical Concept, ed. M. E. Bonine, A. Amanat, and M. E. Gasper, 36-55 (Stanford: Stanford University Press, 2012).

49. N. F. Cantor, Inventing the Middle Ages (New York: William and Morrow, 1991). 


\section{Bibliography}

Adelson, Roger. "British and U.S. Use and Misuse of the Term "Middle East." In Is There a Middle East? The Evolution of a Geopolitical Concept, edited by M. E. Bonine, A. Amanat, and M. E. Gasper, 36-55. Stanford: Stanford University Press, 2012.

Ahmed, S. What Is Islam? Princeton, NJ: Princeton University Press, 2016.

Albrecht, S. "Dār al-Islām and Dār al-Harb." In The Encyclopaedia of Islam, 3rd ed., edited by K. Fleet, G. Krämer, D. Matringe, J. Nawas, and E. Rowson. Leiden: Brill Online. http://dx.doi.org/10.1163/1573-3912_ei3_COM_25867.

Bearman, P. A History of the "Encyclopaedia of Islam." Atlanta: Lockwood Press, 2018.

Becker, C. H. “Der Islam als Problem.” Der Islam 1 (1910): 1-21.

Biesterfeldt, H. H., ed. "Franz Rosenthal's Half an Autobiography." Die Welt des Islams 54 (2014): 34-105.

Browne, E. G. Arabian Medicine. Cambridge: Cambridge University Press, 1921.

Bulliet, R. The Case for Islamo-Christian Civilization. New York: Columbia University Press, 2004.

Caffentzis, G. C. "On the Scottish Origins of 'Civilization." In Enduring Western Civilization, edited by S. Federici, 13-36. Westport, CT: Praeger, 1995.

Cantor, N. F. Inventing the Middle Ages. New York: William and Morrow, 1991.

Esmer, Y. “Is There an Islamic Civilization?" Comparative Sociology 1 (2002): 265-98.

Federici, S. "The God That Never Failed: The Origins and Crises of Western Civilization." In Enduring Western Civilization, edited by S. Federici, 63-89. Westport, CT: Praeger, 1995.

Griffel, F. "Contradictions and Lots of Ambiguity: Two New Perspectives on Premodern (and Postclassical) Islamic Societies." Bustan: The Middle East Book Review 8, no. 1 (2017): $1-21$.

Hartmann, M. “Die Arabistik: Reformvorschläge." Orientalistische Literaturzeitung 1 (1898): 333-42.

Hitti, P. K. Review of Unity and Variety in Muslim Civilization, edited by G. E. von Grunebaum. American Historical Review 61, no. 4 (1956): 931-32.

Hodgson, M. "A Non-Western Civilization Course in a Liberal Education with Special Attention to the Case of Islâm." Journal of General Education 12, no. 1 (1959): 39-49.

-- . The Venture of Islam. 3 volumes. Chicago: University of Chicago Press, 1974. 
Hourani, A. "Islam and the Philosophers of History." Middle East Studies 3, no. 3 (1967): 206-68.

Ibn Khaldūn. Al-Muqaddima. Edited by M. Quatremère. 3 volumes. Paris: Benjamin Duprat, 1858.

Jaeger, W. "Classical Philology and Humanism." Transactions and Proceedings of the American Philological Association 67 (1936): 363-74.

Karamustafa, A. "Islam: A Civilizational Project in Progress." In Progressive Muslims: On Justice, Gender, and Pluralism, edited by O. Safi, 98-110. Oxford: Oneworld, 2003.

Kaufman, W. “Toynbee and Super-History.” Partisan Review 22, no. 4 (1955): 531-41.

Kiesling, L. "Letter of Recommendation: The Life of Marshall Hodgson." New York Times Magazine, October 6, 2016. https://www.nytimes.com/2016/10/09/magazine/letterof-recommendation-the-life-of-marshall-hodgson.html.

Kramer, M. "Arabistik and Arabism: The Passions of Martin Hartmann." Middle Eastern Studies 24, no. 3 (1989): 283-300.

Levy, R. The Social Structure of Islam. Cambridge: Cambridge University Press, 1957.

Lewis, B. “The Roots of Muslim Rage.” Atlantic, September 1990.

Lockman, Z. Contending Visions of the Middle East: The History and Politics of Orientalism. 2nd ed. Cambridge: Cambridge University Press, 1999.

McKeon, R. "The Nature and Teaching of the Humanities." Journal of General Education 3, no. 4 (1949): 290-303.

Meri, J., ed. Medieval Islamic Civilization: An Encyclopedia. 2 volumes. New York: Routledge, 2006.

Minorsky, V. "Iran: Opposition, Martyrdom, and Revolt." In Unity and Variety in Muslim Civilization, edited by G. E. von Grunebaum, 183-206. Chicago: University of Chicago Press. Reprinted as "Persia: Religion and History," in V. Minorsky, Iranica: Twenty Articles, 242-57. Tehran: University of Tehran, 1964.

Morehouse, W. "Asian Studies in Undergraduate Education." The Journal of General Education 11, no. 3 (1958): 125-40.

Nöldeke, Th. Sketches from Eastern History. London: Adam and Charles Black, 1892.

Owen, R. "Studying Islamic History." Journal of Interdisciplinary History 4, no. 2 (1973): 287-98.

Rehatsek, E. Catalogue Raisonné of the Arabic, Hindoostani, Persian and Turkish MSS. in the Mulla Firuz Library. Bombay: Education Society's Press, 1873. 
. Prize Essay on the Reciprocal Influence of European and Muhammadan Civilization during the Period of the Khalifs and the Present Time. Bombay: Education Society's Press, 1877.

Renan, E. L’islamisme et la science. Paris: Calmann Lévy, 1883.

Robinson, C. Islamic Civilization in Thirty Lives: The First 1,000 Years. Berkeley: University of California Press, 2016.

Rosenthal, F. "In Memoriam: Gustave E. von Grunebaum." International Journal of Middle East Studies 4, no. 3 (1973): 355-58.

---, trans. The Muqaddimah: An Introduction to History. 2nd ed. 3 volumes. London: Routledge and Kegan Paul, 1967.

-- - The Technique and Approach of Muslim Scholarship. Rome: Pontificium Institutum Biblicum, 1947.

Singer, M. “Chicago's Non-Western Civilizations Program." Journal of General Education 12, no. 1 (1959): 22-23.

Sorokin, P. A. “Toynbee's Philosophy of History.” Journal of Modern History 12 (1940): 374-87.

Spengler, O. Der Untergang des Abendlandes. 2 volumes. Vienna: W. Braumüller, 1918-22. Translated into English as The Decline of the West. New York: Alfred A. Knopf, 1926-28.

Toynbee, A. J. A Study of History. 12 volumes. London: Oxford University Press, 1934-61.

Von Grunebaum, G. E. "Islam in a Humanistic Education.” Journal of General Education 4, no. 1 (1949): 12-31.

-—-. Medieval Islam. Chicago: University of Chicago Press, 1946.

-_-. "The Problem: Unity in Diversity." In Unity and Variety in Muslim Civilization, edited by G. E. von Grunebaum, 17-37. Chicago: University of Chicago Press, 1955.

Winterer, C. The Culture of Classicism. Baltimore: Johns Hopkins University Press, 2002.

Zwemer, S. M. “Editorial.” The Moslem World, 1, no. 1 (1911): 1-4. 